\title{
Improvement of the technique of calculating operational parameters using an automated system
}

\author{
Yurii Statyvka ${ }^{l}$, Hanna Kyrychenko ${ }^{2}$, Oleh Strelko², Yuliia Berdnychenko, ${ }^{2,}$, Vasyl Gaba ${ }^{2}$, and Tetiana Hrushevska ${ }^{2}$ \\ ${ }^{1}$ National Technical University of Ukraine "Igor Sikorsky Kyiv Polytechnic Institute”, 37, Prosp. Peremohy, Kyiv, 03056, Ukraine \\ ${ }^{2}$ State University of Infrastructure and Technologies, 9 Kyrylivska Street, Kyiv, 04071, Ukraine
}

\begin{abstract}
Impact of the existing operating conditions on terms of cargo delivery and compliance with the rolling stock circulation norms is studied. Planned and actual rolling stock circulation characteristics are analyzed. Deviations from the norms have been detected, which is indicative of non-compliance with technological processes. Nowadays the rolling stock circulation problem becomes more complex; for the service recipients, i.e. customers of the railway, it means delays in cargo deliveries, non-fulfillment of financial obligations before other participants in the railway transport process. A new approach to the methodology and principle of calculating anticipated key performance characteristics are proposed. The existing information technologies for railway management make it possible to monitor compliance with the rolling stock circulation norms and the terms of cargo deliveries and to further improve methods and techniques of performance parameters. This will enable establishing realistic rolling stock circulation norms and cargo delivery terms, thus ensuring compliance with technological requirements of the railway transport processes in order to provide good customer service.
\end{abstract}

\section{Introduction}

The main aspects of the strategy of development of the Ukrainian railways are compliance with the cargo delivery terms, intensification of the rolling stock circulation and improvement of the railway management system based upon information technologies. In our opinion, compliance with the cargo delivery terms and the rolling stock circulation norms is an indication of a perfect technological process upon which the railway operation is based. Unfortunately, currently and in recent years the rolling stock circulation is growing, as stated in the reports of the railway authorities and analysts. Nonconformity with the rolling stock circulation norms and cargo delivery terms is indicative of non-compliance with technological processes. Besides, there exists a significant difference between planned and actual rolling stock circulation. Therefore it is necessary to develop new methods and principles of calculating the key performance parameters.

The aim of this study is to establish principles for the formation of evaluation system for railway cargo transportation efficiency capable of adequate reflecting of the current state of cargo transportation system and improving efficiency of railway cargo delivery.

Subject of the research is the system of quality rating of railway cargo delivery.

The research focuses on the principles for the formation of evaluation system for railway cargo transportation efficiency and mechanism for its creation developed on the basis of circulation data in regard to rail cars which travel to ports' railway stations to be unloaded with subsequent loading on the territories of the corresponding railway divisions.

Scientific novelty of the study lies in development of principles, establishment of feasibility and mechanism of the formation of evaluation system for railway cargo transportation efficiency capable of adequate reflecting of the current state of railway services based upon the statistical data available.

The scientific novelty of the obtained results is in solving urgent scientific and practical problem of increasing the efficiency of using wagons fleet due to the new methodology and principle of calculating and forecasting key performance indicators. In particular, the following scientific results were obtained during the research:

1. Determine the freight cars turnover, based on the actual work, that is reflected in the database of ASFTO UZ - E.

2. It has been proposed to determine the freight cars turnover as an indicator of the service of a certain cargo flow.

3. When carrying out an incomplete wagon cycle on a railway, it has been proposed to calculate the share of each railway in turnover - a full cycle from the first loading to the next loading.

4. According to the turnover data, it has been proposed to calculate the required active fleet of freight cars for the transportation of a certain cargo in a specific rolling stock. 


\section{Literature review and defining problem}

Today the expert community is analyzing different ways of solving the problem of adequate prediction of railway transport processes, taking into account the existing operating conditions [1-6], which will enable establishing realistic terms of cargo deliveries and the rolling stock circulation norms. Also, practicing specialists raise an issue of changing the norm setting principles used for planning rail shipments in order to comply with the cargo delivery terms, to intensify rolling stock circulation and to improve railway management system [7-8]. The issues of efficient use of rail transport and intensification of rolling stock circulation are also studied in publications [9-14] dealing with optimization of operation of industrial enterprises.

As known, average (relative) rail car circulation for a railway network is determined by dividing the number of the rail car fleet by the daily average load [15, p.24], and rail car circulation by circulation elements $[15, p .50]$ is determined the following formula:

$$
O_{v}=\frac{l}{24} \cdot\left(\frac{1}{V_{d}}+\frac{1}{L_{t e x}} \cdot t_{t e x}+k \cdot t_{v a n}\right) \text {, }
$$

where 1 - complete trip of the rail car, $\mathrm{km}$;

$V_{d}$ - the average rail car service speed, $\mathrm{km} / \mathrm{h}$;

$L_{\text {tex }}$ - average run between the train stations, $\mathrm{km}$;

$t_{\text {tex }}$ - average rail car detention at one train station, $\mathrm{km}$;

$k$ - cargo operations/ turn-round ratio;

$t_{v a n}$ - average rail car detention at one train station including loading operations, $\mathrm{h}$.

It is obvious that it's impossible to describe operation of the railway cargo transportation system adequately using average values of a limited number of parameters; that is why actual rolling stock circulation characteristics significantly exceed the values obtained by applying the formula (1). The existing formula do not take into account the rail car maintenance time, although technical condition of the rail car fleet has a significant effect on the rail car operation cycle (turnaround). This is one of the reasons for failures to achieve planned rolling stock circulation figures and its constant intensification [16].

Similar problems exist in the railway administrations of the neighboring states (Russian Railways (RZD), CIS and Baltic countries). In the formulas for calculation of the rolling stock circulation specialists use special coefficients determined by experts; forecasting techniques are also used [17].

Therefore, taking into account considerable difference between the rolling stock circulation characteristics determined on the basis of functional dependency on a limited set of parameters (see formula (1)) and the actual cargo transportation performance characteristics, it is necessary to create a railway cargo transportation efficiency evaluation system that would adequately reflect the railway cargo transportation processes. Such system should comply with the following requirements:

1. standard values must be relevant to the railway cargo transportation process in its current state;

2. if the standard values are exceeded, this is indicative of a problem in the technological process; it helps to find a problematic link in the chain;

3. the efficiency evaluation (norm setting) system should be flexible, i.e., it must be able to correct the standard values in a predictable way depending on the transport system's manageability in regard to reduction of handling time;

4. the efficiency evaluation (norm setting) system should be stable, i.e., not sensitive to accidental or manipulative deviations;

5. the efficiency evaluation (norm setting) system should be safe, i.e., the recommended standard values must not coincide with the boundary efficiency values, in order to avoid constant operation of the system at the limit of its capacity.

At the same time, the railway information system (Ukrzaliznytsia's Rail Freight Traffic Automatic Control System) is a gigantic database which processes information about the work performed, identifies the processes that have taken place [18] and stores information about all operations associated with each rail car. It means that there is a possibility of calculating circulation of each rail car or determining individual performance parameters for a group of rail cars. Similarly, the automated system calculates the time during which each rail car is loaded (to bill the customer), that is a part of the rail car circulation.

So, in order to determine if it is possible to create an adequate efficiency evaluation (norm setting) system based upon Ukrzaliznytsia's information system data, we perform a detailed analysis of data concerning transportation (including batch delivery) of ferrous metals from Kryvyi Rih to Odesa Port.

When developing a new methodology for determining performance characteristics of the railway, it is recommended to take into consideration the following:

The rolling stock circulation should not be calculated using outdated formulas; instead, a rail car circulation should be determined based upon actual operation, which is reflected in the database of Ukrzaliznytsia's Rail Freight Traffic Automatic Control System.

It is recommended to calculate the rolling stock circulation according to the type of the rolling stock used for transportation of a specific cargo, i.e., to determine the rail car circulation as an indicator associated with managing a specific cargo traffic.

If on the territory of a railway authority an incomplete rail car operation cycle (turnaround) takes place, the share of this railway in the circulation (full cycle from loading to the next loading) has to be calculated.

On the basis of circulation data and information about operations performed, it is necessary to determine the rail car fleet required to transport a specific cargo using specific rolling stock. 


\section{Methodology}

In order to analyze the rolling stock circulation parameters of the rail transport processes, data pertaining to shipments (including group shipments) of ferrous metals from Kryvyi Rih to the port of Odessa along several different routes was processed. For analysis of the data a table of train traffic norms in accordance with route timetables has been developed, taking into account handling time at junction points and stations where the locomotive or traction system were changed.

Data concerning the travel time from the starting point of the route to the destination station carriage comprises a part of the parameter - the rolling stock circulation. The second part of the rail car operation cycle is the time when rail cars are on a spur track (feeder line), which is reflected in the database (LOADING or UNLOADING); duration of the operation is analyzed. And finally, the third part is the rail car travel to the next loading or unloading station.

On this route 2242 rail cars were sampled using the following statistical data: average circulation time 10.14, standard deviation — 5.87, median - 8.77, minimal circulation time -2.52 and maximum circulation time - 61.01. Here and hereinafter the time is given in days.

As can be seen from the histogram, see Fig. 1, the sampling includes information about 53 rail cars $(2.4 \%$ of the number of the rail cars sampled) with circulation time of up to 4 days and about 123 rail cars $(5.4 \%$ of the number of the rail cars sampled) with circulation time exceeding 20 days. The rest of the rail cars with circulation time between 4 - and 20 -days amount to $92 \%$ of the number of the rail cars sampled.

To help understand changes in operation of the transportation system on the basis of changes in statistical sampling data, Fig. 2 shows the calculated monthly minimal lower boundary values (Min), upper boundary values (Max), 1st and 3rd quartiles, the median and the average circulation time. The lower and upper boundaries were selected as the values which were distanced not more than 1.5 interquartile range (IQR) from the median. Data which go beyond the Min and Max boundaries is considered outliers and is not presented in the diagrams.

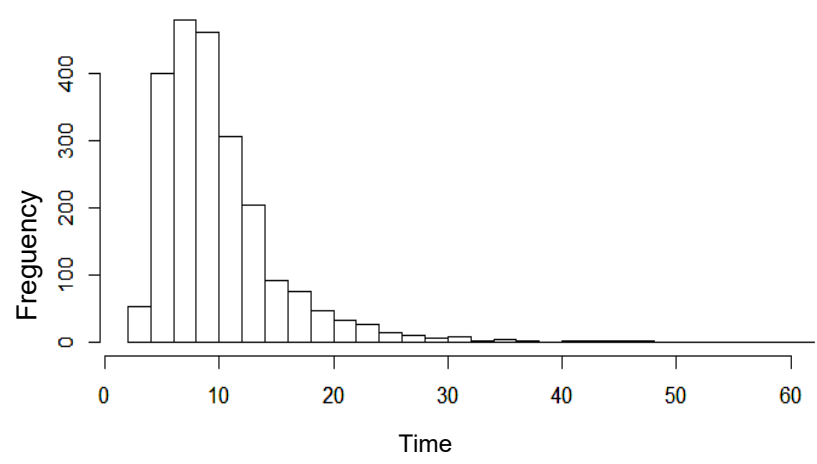

Fig. 1. Distribution of rail car travel time.

As can be seen, the most significant variations are observed for the upper boundary — from 24.30 in
January to 12.53 in September, which amounts to 11.77 days or $48 \%$ of the maximum value. Much less significant absolute variations are observed for the median and the average value. Thus, the average value fluctuated in the range between 12.41 and 7.2, which amounts to 5.21 days or $42 \%$ of the maximum value, and the median - between 11.14 and 6.25 , which amounts to 4.89 days or around $44 \%$ of the maximum value. The most insignificant absolute variations are observed for the lower boundary - from 4.45 to 2.52 , that is 1.93 days or $43 \%$ of the maximum value. Similar changes are observed for the 1st and 3rd quartiles.

Hence, the above mentioned data demonstrates that there exist quite significant variations of all presented statistical characteristics of transportation of the specified cargoes. However, the data truthfully reflects operation of the railway transportation system and may be used as a basis for creation of the efficiency evaluation (norm setting) system.

Thus, the median, being a stable parameter as far as the outliers are concerned, unlike the average value, may be used as a current standard in regard to rail car circulation time. If the rail car circulation time exceeds the median, the loss function (penalty function) must be applied to those entities involved in the activities which caused exceedance of said standard value. In this sampling the median is 8.77 days, and during 7 out of 12 months the monthly sampling median is less than the total sampling median, which attests to the fact that such standard, or norm, is not too demanding. However, of course, it does not exclude selection of the loss function in specific cases, when the circulation time exceeds the median as the standard time value. Selection of the loss function is a separate cargo transportation management issue and requires a separate study.

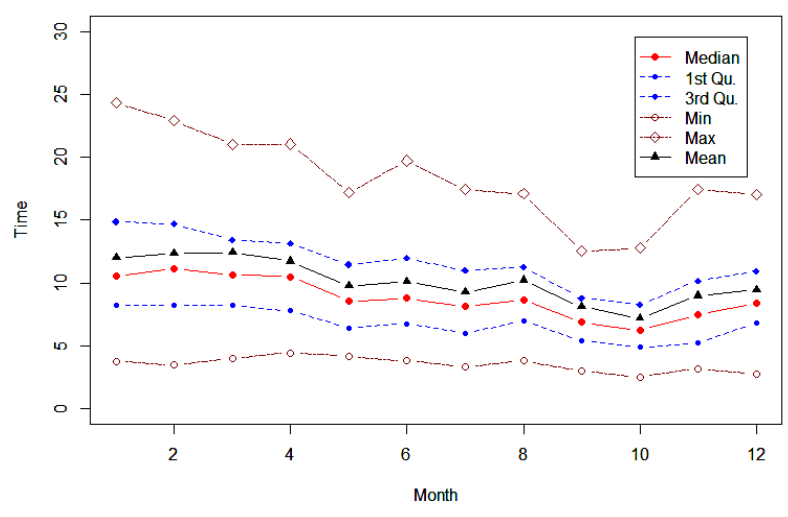

Fig. 2. Changes in rolling stock circulation time.

Based upon the data presented, it can be concluded that at the time of the sampling the state of the cargo transportation system on the specified route has the capacity limit of around 4 days, since such cases amount to only $2.4 \%$, and the lower boundary, as was mentioned earlier, is in the range between 4.45 and 2.52 days.

Thus, the developed efficiency evaluation (norm setting) system complies with the requirements 1), 4) and 5), specified above, since: it is based upon actual conditions; the median is stable in regard to outliers; it 
makes it possible to determine, and thus avoid, boundary values of efficiency - lower boundary values, although the median approaching the lower boundary is practically impossible for such a complex transportation system.

In order to analyses the behavior of the transportation system in more detail, let us consider statistical data pertaining to the sampling that will be built based upon the original sampling, separating only data concerning rail cars, the full circulation cycle of which began and ended on the territory of Prydniprovska Railway. With this, we exclude from the original sampling the data concerning rail cars which were subsequently loaded not on the territory of Prydniprovska Railway, but on the territory of Odesa Railway or any other railway division.

The sampling arranged in this way (let us call it S2) contains information about circulation of 1632 rail cars with the following statistical data: average circulation time - 10.35, standard deviation - 5.61, the median 9.00, minimal circulation time -3.16 and maximum circulation time -53.28 (see Fig. 3).

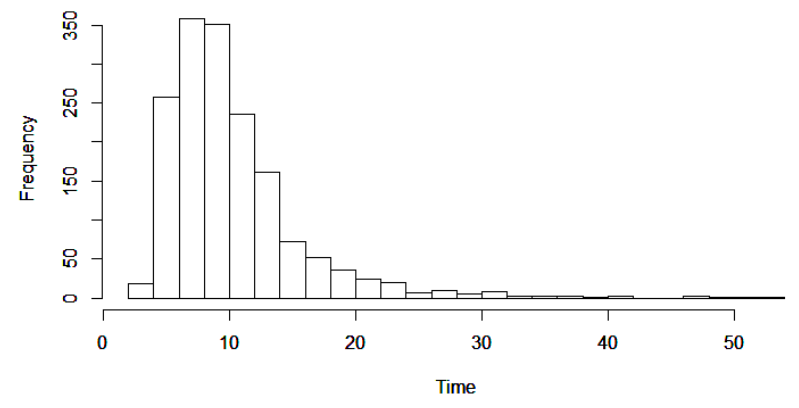

Fig. 3. Diagram of S2 sampling.

Comparison of time during which the rail cars travelled through the territory of Prydniprovska Railway, Fig. 4, and Odesa Railway, Fig. 5, illustrates performance of the transportation system operation, using the travel of the same rail cars as an example. In particular, diagrams of time series quantiles of the time during which the rail cars travelled through the territory of Prydniprovska Railway and Odesa Railway, Fig. 6, show that from among the rail cars with travel time less than 3 days around $30 \%$ of their total number travelled through territories of both Odesa and Prydniprovska Railway. However, at shorter time intervals Prydniprovska Railway showed higher efficiency - for $10 \%$ of rail cars with the shortest travel time on the territory of Prydniprovska Railway it did not exceed 1.8 days, while on the territory of Odesa Railway it was 2.58 days. On the other hand, at longer time intervals the rail cars travelled faster on the territory of Odesa Railway with the median of 3.74 against 4.65 on the territory of Prydniprovska Railway, i.e., the median for Odesa Railway was less by almost one day (0.91 days). And the 90th percentile of travel time on the territory of Odesa Railway was less than the corresponding value for Prydniprovska Railway by 4.32 days.

The relationship mentioned above is defined by the entire set of factors which have an impact on the rail car circulation time - nomenclature and quantity of cargo handling operations, mileage, organizational and other features of specific railway divisions and can hardly be harmonized in a rational way. Therefore, in order to ensure compliance with the requirements in regard to relevance of the efficiency evaluation (norm setting) system to the actual state of the transportation system, we think it expedient to consider operation of each railway division a separate subsystem and to adopt the following standard median values — 4.65 days for Prydniprovska Railway and 3.74 days for Odesa Railway. Boundary efficiency values can be taken as 5\% quantile - 1.52 and 2.44 for Prydniprovska Railway and Odesa Railway respectively.

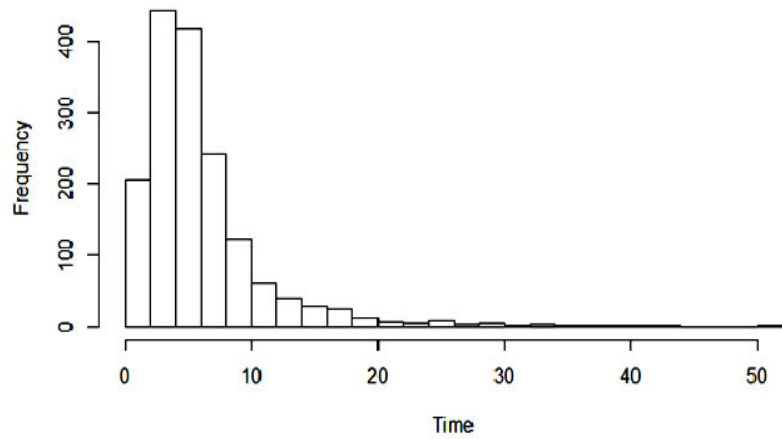

Fig. 4. Distribution of rail car travel time on the territory of Prydniprovska Railway.

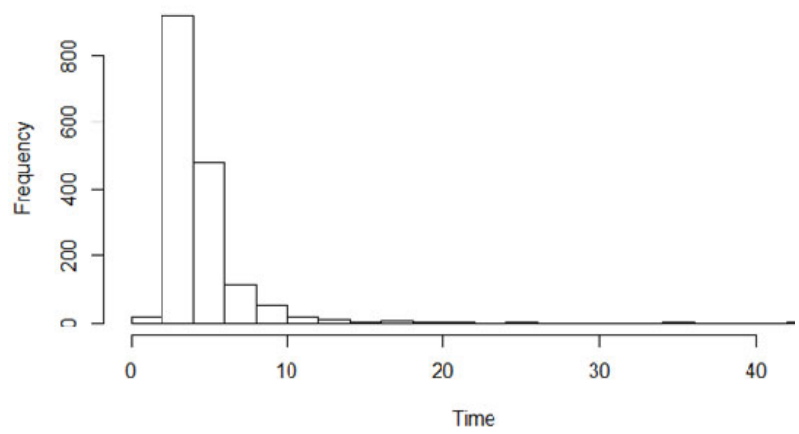

Fig. 5. Distribution of rail car travel time on the territory of Odesa Railway.

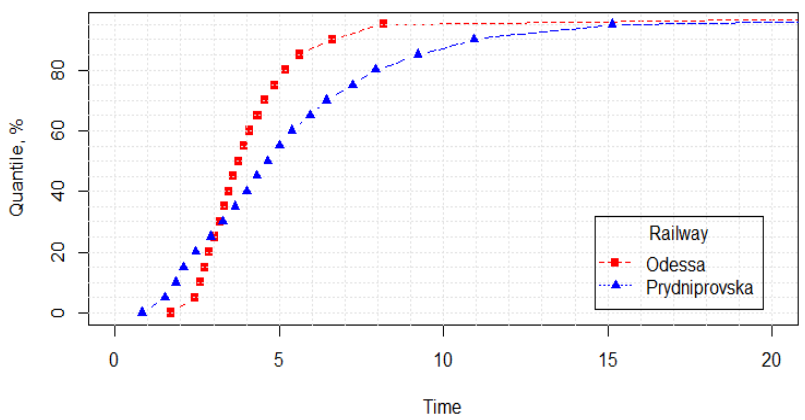

Fig. 6. Quantiles of rolling stock travel time distribution

In order to ensure compliance with the requirement 2 ) in regard to the efficiency evaluation (norm setting) system, let us determine distribution of S2 sampling rail cars according to the time during which they travel through the territory of each of the railway divisions compared to statistical data for the corresponding railway division. 
In order to analyze the period of time during which rail cars were on the territory of different railway authorities (during operation cycle), let us make a logical substitution $b_{1}=t^{\text {Od }}>$ bound $^{\text {Od }}$, which adopts the value "true" if during the rail car travel on the territory of Odessa Railway $t^{\text {Od }}$ is bigger than the value of the travel boundary parameter pertaining to Odessa Railway bound $^{\text {od }}$. Similarly, let us make a logical substitution for Prydniprovska Railway $b_{2}=t^{P_{r}}>$ bound $^{P r}$.

We will substitute bound ${ }^{\text {Od }}$ and bound ${ }^{P r}$ with bound $^{R}$, where $R \in\{O d, P r\}$. If bound ${ }^{R}$ is the average value of time during which the rail cars travel through the territory of a specific railway $R \in\{O d, \operatorname{Pr}\}$, we will substitute bound ${ }^{R}$ with mean ${ }^{R}$.

Table 1 presents data regarding sampling of rail cars according to the travel boundary bound ${ }^{R}$ with values of the 25 th percentile, median, mean value and the 75 th percentile.

We will suppose that the rail car belongs to rail car type 1, if the period of time during which it is on the territory of Odessa Railway exceeds the value of bound ${ }^{\text {Od }}$, specified in the table column, only for Odessa Railway, but not for Prydniprovska Railway (i.e., the same rail car's travel time on the territory of Prydniprovska Railway is less than the value of bound $^{P r}$ ). Rail cars of type 2 include those rail cars the travel time of which exceeds the value of bound ${ }^{P r}$ only on the territory of Prydniprovska Railway, and on the territory of Odessa Railway the travel time is less than the value of bound $^{\text {Od }}$. Rail cars of type 3 include those rail cars the travel time of which exceeds the value of bound ${ }^{R}$ on the territory of both railways. And, finally, type 4 means the rail cars, the travel time of which does not exceed the value of bound $^{R}$ on each of the railways.

Table 1. Sampling of rail cars according to the travel boundary.

\begin{tabular}{|c|c|c|c|c|c|}
\hline $\begin{array}{c}\text { Row } \\
\text { No }\end{array}$ & bound $^{R}$ & $\begin{array}{c}1, \% \\
b_{1} \wedge \overline{b_{2}}\end{array}$ & $\begin{array}{c}2, \% \\
\overline{b_{1}} \wedge b_{2}\end{array}$ & $\begin{array}{c}3, \% \\
b_{1} \wedge b_{2}\end{array}$ & $\begin{array}{c}4, \% \\
\overline{b_{1}} \wedge \overline{b_{2}}\end{array}$ \\
\hline 1 & $t_{0.25}^{R}$ & 17,8 & 18 & 57 & 7,2 \\
\hline 2 & $t_{0.5}^{R}$ & 24,6 & 24,6 & 25,4 & 25,4 \\
\hline 3 & mean $^{R}$ & 21.93 & 21.93 & 13.23 & 42.89 \\
\hline 4 & $t_{0.75}^{R}$ & 18,8 & 18.3 & 6.7 & 56,7 \\
\hline
\end{tabular}

Every sampled S2 rail car can belong only to one type, and combination of the four rail car types represents complete sampling S2.

As can be seen from Table 1, the numbers of rail cars of types 1 and 2 respectively are very close for different values of bound ${ }^{R}$. Together they give an idea about the number of rail cars which overstepped the corresponding boundary bound $^{R}$ only on the territory of one of the railways.
Thus, in line No 2 of the table we see that almost 50 per cent of rail cars (49.2\%) are among the half of the rolling stock with the longest travel time (exceeding the median for the corresponding Railways) only due to the problems occurring on the territory of one of the Railways. It is possible that it was due to common problems that $25.4 \%$ of rail cars had travel time which exceeded the median on the territory of both Railways at the same time - type 3. Travel time of the remaining $25.4 \%$ of rail cars is less that the median value for both Railways.

As far as the rail cars with bound $^{R}=$ mean $^{R}$, see line No 3 of the table. It is easy to see that over $57 \%$ of rail cars have travel time which exceeds the average value for the corresponding Railways. With this, it should be noted that in $44 \%$ of the cases it was due to problems occurring on the territory of one of the Railways, and $13 \%$ of the rail cars exceeded the average travel time for both Railways.

Thus, percentage of rail cars which were delayed only on the territory of one railway division is from $35.8 \%$ to $49.2 \%$.

Such analysis also makes it possible to establish the area of responsibility of each of the railway divisions within the boundaries of the entire system. In order to do that we will create sampling S3 based upon sampling S2, leaving only those rail cars the circulation time of which exceeds the circulation time median on a specified route in the original sampling -8.77 days. The corresponding calculation results are given in Table 2 .

It can be noted that the rail cars the delay of which was caused by only one railway division amount to $19.7 \%-67.7 \%$. With this, from among all rail cars the circulation time of which exceeds the median 8.77 days, $16.6 \%$ of rail cars were delayed exclusively with exceedance of their own median within the boundaries of Odesa Railway, $34.0 \%$ - exclusively with exceedance of their own median within the boundaries of Prydniprovska Railway, and $48.4 \%$ - their own median values were exceeded on the territories of both railway divisions.

Thus, we can state that the proposed approach to the formation of efficiency evaluation (norm setting) system complies with the requirement 2) in regard to localization of the problematic link.

Table 2. Calculations for rail cars the travel time of which exceeds the circulation time median value for the specified route.

\begin{tabular}{|c|c|c|c|c|c|}
\hline $\begin{array}{c}\text { Row } \\
\text { No }\end{array}$ & bound $^{R}$ & $\begin{array}{c}1, \% \\
b_{1} \wedge \overline{b_{2}}\end{array}$ & $\begin{array}{c}2, \% \\
\overline{b_{1}} \wedge b_{2}\end{array}$ & $\begin{array}{c}3, \% \\
b_{1} \wedge b_{2}\end{array}$ & $\begin{array}{c}4, \% \\
\overline{b_{1}} \wedge \overline{b_{2}}\end{array}$ \\
\hline 1 & $t_{0.25}^{R}$ & 3,6 & 16,1 & 79,5 & 0,1 \\
\hline 2 & $t_{0.5}^{R}$ & 16,6 & 34,0 & 48,4 & 1,0 \\
\hline 3 & mean $^{R}$ & 26,7 & 41,0 & 25,2 & 7,1 \\
\hline 4 & $t_{0.75}^{R}$ & 27,8 & 34,7 & 12,8 & 24,5 \\
\hline
\end{tabular}

As far as the requirement 3 ) is concerned (flexibility of the norm setting system), it is worth noting that 
flexibility (adaptability) is by all means is connected with selection of the loss function. However, it is clear that the loss function intended to reduce the number of rail cars the circulation time of which exceeds the median has to reduce the median itself, which eventually will be adopted as the standard value.

\section{Conclusion}

The study established the basic the formation of evaluation system for railway cargo transportation efficiency (norm setting) relevant to the actual state of the railway, which pertain to the requirements in regard to 1) relevance, 2) possibility to locate problematic links (sections), 3) flexibility (adaptability), 4) stability and 5) safety.

The possibility of creating such efficiency evaluation (norm setting) system has been demonstrated using Ukrzaliznytsia's information system data and circulation time of the rail cars which travel to ports' railway stations to be unloaded with subsequent loading on the territories of the corresponding railway divisions.

It was shown that relevance is ensured by using statistical data in regard to operation of the corresponding transportation subsystem, and stability and safety are ensured by using order statistics - for example, the median and the lower boundary (or the 5th percentile). The issue of the subsystem's size requires further research; however, the natural limit is the requirement to have the statistical data base sufficient to make well-grounded conclusions, i.e., it is defined by cargo handling efficiency.

It was proven that such system is capable of locating problematic sections and areas of responsibility of the subsystems, for example, by applying the method which is described here and which involves breaking the rail car fleet into separate categories (four in this particular case).

Flexibility (adaptability) of the system is ensured by linkage of the standard values to the order statistics that, provided the loss function is chosen properly, will be reduced due to reduction in the number of values which exceed the standard values. The problem of a rational, and moreover optimal, selection of the loss function requires a separate study.

Future research directions: the authors intend to study the issue of selecting the subsystem's boundary limits and evaluating flexibility (adaptability) depending on the loss function, using the statistical data available and mathematical modelling of railway cargo transportation processes.

\section{References}

1. E. Z. Zinder, SUBD i deystvitelno bolshie sistemyi, Sistemyi upravleniya bazami dannyih: elektron. versiya zhur (Aug. 2018). [Online]. Available: https://www.osp.ru/news/articles/1997/0801/130315 55\#part 1.

2. F. Y. Wang, Toward a revolution in transportation operations: AI for complex systems, Intelligent
Systems: IEEE, 23 (6), 8-13 (2008). 10.1109/MIS.2008.112

3. H. I. Kyrychenko, O. H. Strelko, Yu. A. Berdnychenko, S. V. Hurinchuk, Automation of Work Processes at Ukrainian Sorting Stations, International Journal of Engineering \& Technology, 7 (2.23), 516-518 (2018). doi: 10.14419/ijet.v7i2.23.15346

4. N. A. Kuznetsov, F. F. Paschenko, N. G. Ryabyih, E. M. Zaharova, I. K. Minashina, Algoritmyi optimizatsii $\mathrm{v}$ zadachah planirovaniya na relsovom transporte, Informatsionnyie protsessyi, 14 (4), 307318 (2014).

5. H. I. Kyrychenko, O. H. Strelko, Yu. A. Berdnychenko, O. V. Petrykovets, O. A. Kyrychenko, Modeliuvannia stsenariiv peremishchennia vantazhu u lantsiuhakh dostavky, Transportni systemy ta tekhnolohii perevezen, 12, 32-37 (2016). doi: 10.15802/tstt2016/85882.

6. H. Kyrychenko, Yu. Statyvka, O. Strelko, Y. Berdnychenko and H. Nesterenko. Assessment of cargo delivery quality using fuzzy set apparatus, International Journal of Engineering \& Technology, 7(4.3), 262-265 (2018).

7. Rozporiadzhennia kabinetu ministriv Ukrainy «Pro skhvalennia Natsionalnoi transportnoi stratehii Ukrainy na period do 2030 roku» vid 30 travnia 2018 roku № 430-r Kyiv. [Online]. Available: https://zakon.rada.gov.ua/laws/show/430-2018$\% \mathrm{D} 1 \% 80$

8. Stratehii rozvytku PAT “Ukrzaliznytsia” na 2017 2021 roky, PAT «Ukrzaliznytsia» (2017).

9. N. Ueno, Y. Nakagawa, S. Morito and Y. Okuno, Steel product transportation and storage simulation: A combined simulation/optimization approach, 1988 Winter Simulation Conference Proceedings, San Diego, CA, USA, 678-683 (1988).

10. A. O. Lyamzin. Efficiency of the transport system of the industrial region in the port logistics chain of grain supply: author's abstract Theses for Cand. of Tech. Sci., 20 (2008).

11. A. Dávid. Innovation of handling systems in the world container ports and their terminals Proceedings of the 17th International Conference Transport Means (Kaunas) (Kaunas: University of Technology) 250-253 (2013).

12. O. L. Petrashevsky, A. M. Redzyuk and O. V. Alekseenko. Methodology of conceptual-logistic mapping and project modeling of the objectives of the traffic safety management system NTU, Collection of Scientific Articles, 6(10), 76-89 (2009).

13. N. I. Shapkin. Organization of rail transportation based on discrete methods of management and a strict schedule of trains traffic Transport. Science, Technology, Management, 8, 2-8 (2008). 
14. M. Marinov, T. Zunder, P. Mortimer, Rail Freight Services, World Transport, Policy \& Practice, 18(2), 30-38 (2012).

15. M. V. Makarenko Kratkiy spravochnik pokazateley ekspluatatsionnoy rabotyi zheleznyih dorog Ukrainyi. Uchebnoe posobie (2001).

16. H. Ye. Bohomazova, Formuvannia avtomatyzovanoi tekhnolohii upravlinnia vahonopotokamy na zaliznychnykh napriamkakh, Avtoreferat dysertatsii na zdobuttia naukovoho stupenia kandydata tekhnichnykh nauk, Kharkiv (2019).

17. Rasporyazhenie OAO "RZhD" ot 18.08.2015 N 2075r "Ob utverzhdenii "Metodiki tehnicheskogo normirovaniya, ucheta rabochego parka i vremeni oborota gruzovogo vagona na infrastrukture obschego polzovaniya" i ustanovlenii statisticheskogo nablyudeniya za pokazatelyami ispolzovaniya gruzovyih vagonov na infrastrukture obschego polzovaniya", 14-17 (2015).

18. H. I. Kyrychenko, Metodyka stvorennia intelektualnoi avtomatyzovanoi systemy upravlinnia dostavkoiu vantazhiv na zaliznytsi, Nauka ta prohres transportu. Visnyk Dnipropetrovskoho natsionalnoho universytetu zaliznychnoho transportu, 2(68), 46-55 (2017). doi: $10.15802 / \operatorname{stp} 2017 / 99950$. 